\title{
Comment on Article by Anderson and Seltzer
}

\author{
Charles Louis Kincannon*
}

Margo Anderson and William Seltzer's "Federal Statistical Confidentiality and Business Data: Twentieth Century Challenges and Continuing Issues," like similar papers in the past, presents compelling points and insights about the maturation of confidentiality as a concept and principle within the federal statistical system.

Yet, in discussing this important principle, Anderson and Seltzer gratuitously raise doubts about the Census Bureau's former leaders, by conflating the lack of a coherent, organized official record with conspiracy motives. As I understand from colleagues, the Census Bureau archives from that era, as well as many other agencies' archives, are not as comprehensive or organized as historians may prefer. Many of the materials in the Census Bureau's records for this time were gathered from the personal files collected over the years by Philip Hauser, who served as Deputy Director.

Anderson and Seltzer suggest that the lack of consistent and comprehensive documentation in the archives may result from a cover-up: "the evidence has either been forgotten, deliberately hidden, obfuscated, or otherwise lost to later generations of officials in the statistical system and the general public." Yet, as they well know, their suggestion conflicts with the fact that the Census Bureau's archives contain evidence of disclosures in response to the Second War Powers Act. ${ }^{1}$

It is equally important to understand the evolution of the nation's statistical system and the maturing concept of confidentiality. At the time of the Second War Powers Act, the Census Law did not provide the same level of authority for confidentiality as the current law. From the 1930s through the 1960s, the federal system experienced expansion, with methodological advances accompanying societal changes. Throughout these years, the concept of confidentiality developed and matured, and was ultimately recognized as a fundamental principle. In fact, a critical principle for federal statistical agencies, "Trust Among Data Providers," states, "a federal statistical agency must have a relationship of mutual respect and trust ultimately with respondents," and that "maintaining confidentiality, in particular, precludes the use of individually identifiable information for any administrative, regulatory, or law enforcement purpose." ${ }^{2}$ This principle is echoed worldwide in the United Nations' Fundamental Principles of Official Statistics. ${ }^{3}$

Confidentiality is the foundation of mutual respect and trust between respondents and statistical agencies. It is also, as history demonstrates, an important test for society. Anderson

\footnotetext{
${ }^{*}$ Director, U.S. Census Bureau, 2002-2008, mailto:clkincannon@aol.com

${ }^{1}$ Two particularly insightful documents dated 4 December 1942 summarized the tabulations prepared during 1942 by the Census Bureau. Though lacking any specific reference to the Second War Powers Act, the lists contain microdata disclosures of both demographic and economic data, as well as other tabulations and reports. The documents are available at the National Archives as: Bureau of the Census, "War Activities of the Bureau of the Census," 4 December 1942, NADC, Records of the Bureau of the Census, RG 29, Office Files of Philip M. Hauser, File: War Work Reports.

${ }^{2}$ Committee on National Statistics, Principles and Practices for a Federal Statistical Agency, ed. Margaret E. Martin, Miron L. Straf, and Constance F. Citro, 3rd., (Washington, DC: The National Academies Press, 2005), 4-5

${ }^{3}$ United National Statistical Division, Fundamental Principles of Official Statistics, 15 April 1992, (3 January 2008), http://unstats.un.org/unsd/methods/statorg/FP-English.htm
} 
and Seltzer correctly point out that challenges to confidentiality undermine the credibility and integrity of statistical agencies. However, attempting to encourage intrigue and manufacturing negative motives is a distraction, and it undermines, by association, the credibility of today's statistical agencies. In responding to a crisis, as we have seen with World War II and the terrorist attacks of 9-11, laws may change. The question is whether we are prepared to confront such challenges.

I believe the Census Bureau can successfully confront them and I offer these final thoughts in considering those challenges. First, it is important to remember that producing federal statistics is a public trust - the fundamental uses of data produced by a statistical agency are to guide public policy discussions and inform decision-making for both the public and private sectors. The data serve real-world needs - they are used to develop public policies, make decisions, and measure outcomes. Data must answer the important questions: Is the economy growing stronger? Are government policies providing an economic climate conducive to creating new jobs? How many children are going to school and attaining their degrees? The ability of government, business, and most importantly our citizens to make good decisions about policies, investments, and other important issues depends on the quality of the data.

Second, quality, in many senses, is dependent on the high response rates that stem from the public's cooperation. Therefore, confidentiality is a critical component of quality-we must strive to keep our commitment to protect the respondent's answers in order to provide the country with the information it needs.

But third, we must also remember that federal statistical agencies are members of a vast community that includes a diverse range of stakeholders. Those stakeholders have needs and concerns that are, in many instances, non-technical and must be weighed against technical needs and concerns, as well as our fundamental principles.

Tension will often result - but do not hide from the challenges. Listen closely to the stakeholdersrespect their perspectives and learn what questions they are willing to answer. Facing these challenges, more often than not, will result in better statistical data for everyone as we seek creative ways to respond to stakeholders' needs. 